\title{
JOÃO JOSÉ COCHOFEL E A RECUSA DO IMAGINÁRIO SIMBOLISTA/DECADENTISTA
}

\author{
Chimena Barros da GAMA (UNESP/Araraquara - FAPESP)
}

REUSMO: O trabalho ora apresentado objetiva a análise de composições de Sol de Agosto, do poeta coimbrão João José Cochofel, a fim de refletir sobre seu diálogo com a poética do Simbolismo/Decadentismo português e de outros países como a França. Livro importante para a poesia lusitana, surgido no início dos anos 40, pouca crítica (embora com nomes de peso como Eduardo Lourenço e Fernando Guimarães) atenta para o fato de que a lírica de Cochofel rompe com resquícios do lirismo simbolista em voga ainda no século XX (bem como com a eloquência presencista). O fato é que o autor foi membro do grupo neo-realista português, e fatores problemáticos surgem quando se pensa na poesia de uma tendência literária tão engajada. Porém, Cochofel, exatamente ao afirmar sua lírica do concreto e baseada nos sentidos, e ao negar o imaginário simbolista/decadentista, consegue ser o maior poeta da vertente, excedendo os limites do discurso teórico, crítico e literário do grupo ao qual pertenceu.

PALAVRAS-CHAVE: Poesia portuguesa; João José Cochofel; Sol de Agosto; Simbolismo/Decadentismo; Neo-realismo.

ABSTRACT: The presented report has as purpose to analyze Sol de Agosto's compositions, by João José Cochofel, poet from Coimbra, with the objective to think about his dialogue with Simbolism/ Decadentism portuguese poetics and from another countries, like France. Important artwork to Portuguese poetry, emerged in the early's 40, a few critics (although important names as Eduardo Lourenço and Fernando Guimarães has pondered about it) realize the fact that Cochofel's lyric breaks off with symbolism lyrism fragments, still popular in the twenty century (as well the presencista "eloquence"). The fact is that the writer was a member of the Portuguese group called "neo-realista" and, when we think about poetry of a literary tendency so engaged, problems came out. However, Cochofel, when he affirms his lyric of the concrete and base on the sense, and when he denies the symbolist/decadentist imaginary, he is the best poet of the group, going beyond the limits of the theoretical discourse, critic and literary of the group in which he was insert.

KEYWORDS: Portuguese poetry; João José Cochofel; Sol de Agosto Simbolism/Decadentism; Neo-Realismo 
A poesia portuguesa de meados do século $\mathrm{XX}$ é devedora das mais diversas tendências modernas fundadas no século anterior: os primeiros "modernos" portugueses, como António Nobre e Camilo Pessanha, além de contribuírem para a fixação do imaginário simbolista em seu país, trouxeram ao gênero lírico lusitano variadas inovações formais no verso, na metafórica, na desconstrução do poema clássico, continuadas por autores do século XX como Sá-Carneiro e Fernando Pessoa. Tanto o autor de "Dispersão" quanto o poeta heteronímico deram continuidade a inovações simbolistas, somando-as a procedimentos vanguardistas ou ultrapassando-as - e o caso de Pessoa deve ser tomado sempre à parte, como singular. Depois de Orpheu, não se pode afirmar que a poesia da Presença tenha sido grande continuadora de inovações e revoluções poéticas órficas, como lembra o singularíssimo ensaio de Eduardo Lourenço, "Presença ou a contra-revolução do modernismo português?" (LOURENÇO, 1987); porém, é certo que com as novidades empreendidas desde o oitocentismo, por poetas portugueses e franceses, o gênero poético lusitano do século XX aproveitou-se deveras do imaginário e das transformações simbolistas.

É dentro deste contexto de heranças oitocentistas, somada a experimentos linguísticos os mais diversos, que em Portugal surgiu a poesia de João José Cochofel (1920-1981). Embora este autor seja pouco lembrado e quase que "relegado" pela sua manifesta filiação ao movimento neo-realista português - e o Neo-Realismo não era, para a poesia, a "arte desinteressada" -, certo é que, como atestam alguns curtos ensaios de críticos como Gastão Cruz (1973) e Fernando Guimarães (1988), este poeta, de uma simplicidade não simplista - mas clara, apolínea -, tem papel importante nos rumos da arte poética lusitana ao publicar Sol de Agosto, obra de 1941. Paradoxalmente, o livro faz parte da coleção de poesias "Novo Cancioneiro", promotora de outros artistas do Neo-Realismo, como Fernando Namora e Carlos de Oliveira, e de escritos "poéticos" bastante duvidosos como os de Sidónio Muralha e Francisco José Tenreiro. E o paradoxo está no fato de que a coleção propagou muita poesia panfletária e mensageira, no sentido mais negativo das palavras, e, em compensação, trouxe à luz a poética de Cochofel em livro que, segundo Cruz, é "obra-chave da poesia portuguesa de 40" (CRUZ, 1973, p.53). 
Trata-se da coletânea de um autor de apenas vinte e um anos, mas não foi sua estreia como poeta (houve duas recolhas antes). No entanto, é nessa terceira obra que encontramos o Cochofel de obras mais maduras como Uma rosa no tempo (1968), um de seus oito livros publicados em sessenta anos de vida.

No presente artigo, trataremos os poemas de Sol de Agosto partindo de seu diálogo com idéias e preceitos poéticos em voga desde o Romantismo, mas aprofundadas no, e relacionadas sobremaneira ao Simbolismo/Decadentismo. É recusando tais postulados (como as "crises de alma", o culto à fantasia e o esteticismo), que João José Cochofel afirma uma poética do instante e da vivência sensível, que levou o crítico Eduardo Lourenço a chamá-la de "Poesia da imanência" (1983).

\section{Presença do Simbolismo/Decadentismo na literatura novecentista}

O Simbolismo e o Decadentismo difundiram concepções poéticas e posturas literárias marcantes para o âmbito de toda poesia posterior: a ruptura radical (iniciada já no Romantismo) e definitiva com a poesia clássica trouxe à voga, tanto em termos formais como no âmbito das ideias, imagens e pressupostos deveras relacionados à figura do poeta e a suas criações nas obras dos "pais" do Simbolismo, Baudelaire e Mallarmé: esteticismo, busca de uma forma tão nova e absoluta para "o poético", que este se tornara linguagem cifrada, despersonalização, culto à imaginação, a consagração, enfim, de um mundo à parte, o da poesia - o da própria linguagem ou aquele formulado pela interioridade do poeta, alguém muito singular.

O Romantismo iniciou tal renovação da poesia, sobretudo devido ao idealismo alemão e ao novo recorte que este deu à lírica e ao poeta, em contraste com o autor de poesia clássica; podemos dizer, então, que o ponto de partida para transformações no gênero lírico foi o movimento romântico, mas que o Simbolismo francês foi o ápice de tais transformações.

São célebres os trabalhos acerca do impacto de configurações simbolistas (e decadentistas) na literatura do século XX, como os do francês Guy Michaud, apontando 
as obras de Paul Valéry e Marcel Proust como devedoras do Simbolismo e do Decadentismo (1966, p.546-593), ou o importante estudo de Hugo Friedrich, cuja obra Estrutura da Lírica Moderna, não se esquecendo dos grandes contributos dos românticos alemães e ingleses para a poesia da Modernidade, parte, sobretudo, de Baudelaire, Mallarmé e Rimbaud para traçar uma linha que chega à lírica do século XX. E, conforme o crítico, esta não é fundamentalmente nova, pois é herança dos autores pais da poesia da modernidade - simbolistas -, mas é original (1978, p.141).

Quanto à cena literária lusitana, os estudos de Fernando Guimarães, Poética do Simbolismo em Portugal (1990) e Simbolismo, Modernismo e Vanguardas (1992), são livros fundamentais para se entender o quanto o Simbolismo/Decadentismo colaborou para o estabelecimento de uma poesia efetivamente moderna em Portugal, inclusive, para a formação do primeiro Modernismo português.

António Nobre e Camilo Pessanha foram, reconhecidamente, como já afirmamos, pais da poesia moderna portuguesa; João Gaspar Simões considerou o poeta do Só o "precursor da poesia moderna" (19_) em Portugal, e Pessanha, como lembra Guimarães, teve sua poética como base para grandes transformações ocorridas nas composições da geração de Orpheu, inclusive nas de Pessoa (1992, p.37). Parece indubitável que o curso da lírica portuguesa foi transformado, após as poesias francesas de Baudelaire e Verlaine (o autor de "Art poétique" foi muitas vezes emulado e até ultrapassado por Pessanha e outros líricos portugueses oitocentistas), e após as poesias dos autores do Só e da Clepsidra. Aliás, Pessanha foi um poeta muito importante para alterações na lírica portuguesa, pois sua revolução deu-se em todos os níveis da poesia: na métrica, na sintaxe (com suas desarticulações), na adjetivação, na metáfora; enfim, o poeta tem grande importância para os rumos da poesia portuguesa.

Com efeito, é fato que não apenas as inovações formais, tais como a ruptura com versos clássicos e a inovação da sinestesia como figura central, capaz de mover a metáfora também para a sonoridade absoluta, mas ainda as idéias da sugestão, da transfiguração lírica, das correspondências, o culto ao sonho, a noção de palavra como depositária de encantamento, a singularidade do poeta, encastelado na torre de marfim, enfim, todas essas concepções fortes no Simbolismo foram devoradas por poetas do 
século XX, cada qual ao seu modo. Embora alguns desses traços relacionados aos simbolistas sejam um tanto quanto "vagos" - "magia das palavras", "encantamento", "fantasia", "poeta maldito" (e, aliás, a própria noção de "vago", "indeciso", algo que não se pode apreender, é inerente ao objeto poético simbolista) - elas surgem quando o assunto é a poesia a partir da segunda metade do século XIX, e, de forma sistematizada, tornam-se parte de uma lista de tópicos comuns aos fundadores da Modernidade poética. É nesse sentido que Chiampi formula a idéia de que românticos alemães e mais profundamente os simbolistas franceses,

para se oporem à mediocridade da vida burguesa, defenderam o rêve, a fantasia, o erotismo, o poder mágico das palavras e a linguagem primigênia, capaz de resgatar o tempo anterior à história. (CHIAMPI, 1991, p.15, negrito nosso).

Ademais, autores relacionados à poética do fin-de-siècle adotaram postura lírica que talvez possamos chamar de "individualista", ou, pensando em termos filosóficos, “idealista”. O crítico português José Carlos Seabra Pereira (1975), enumerando o que chamou "Espírito e temas da poesia Decadentista e Simbolista", menciona a "mundividência idealista" (p.369), ou seja, a crença no mundo como reflexo do "eu", da visão do sujeito, de sua ideia. Evidentemente, nos poetas do final do século XIX, simbolistas e (ou) decadentistas, esta postura está vinculada à filosofia de Schopenhauer, representante de um idealismo interessante aos autores oitocentistas. Mas não só a herança desse pensamento, como outros traços dessa poética também refletem no culto ao sujeito e à sua cosmovisão, à sua ideia das coisas: a evasão, a maldição de ser poeta, e, por consequência, ter a sensibilidade mais suscetível e a chamada "gnose poética do eu" (PEREIRA, 1975, p.360) são marcas de uma poesia que só poderia ter como traço fundamental a revolução da linguagem - já que esta deveria encerrar algo de singular no indivíduo (e eis um grande contraste com a poética clássica) - e a fixação em si mesma enquanto arte.

Notadamente, trata-se também de uma postura que, embora bastante criticada por autoresengagés do século XX - porque tida como "alienada" - manifesta, certamente, um gesto crítico em relação à época e seus costumes. Apenas não foi um 
gesto de denúncia; antes, para usar palavra semelhante, foi atitude de renúncia - e eis uma grande diferença em relação aos românticos de faceta social, idealistas, sim, mas considerados os salvadores do "povo". O poeta simbolista/decadentista, em contrapartida, renunciava à luta pela mudança do mundo, preferindo, primeiro, mudar a arte, esta realmente sob seu domínio, e reforçava-se, assim, a célebre ideia de "arte pela arte", cujas origens estão em Théophile de Gautier[1].

Um importante documento reflexivo a respeito dos traços artísticos devedores do Simbolismo, na Europa, é o ensaio de Ortega y Gasset intitulado "La deshumanización del arte". Interessa-nos principalmente como o testemunho que o pensador dá de um acontecimento artístico diferente, observado por ele nos anos 20 (o ensaio é de 1925). A tese de que esta arte é "antipopular" e que tem a massa contra si porque esta "no la entiende" (ORTEGA Y GASSET, 1964, p.16) lembra-nos o desejo dos poetas dos finais do século XIX (Mallarmé, sobretudo), de empreender uma poesia para "iniciados". Em outro ponto, as especulações feitas pelo autor espanhol sobre esta arte, então "jovem", remetem-nos a Baudelaire: segundo Ortega y Gasset, nela celebra-se a "deformação da realidade", a "desumanização da realidade", e o triunfo do estético sobre o humano (p.36) - e não seria esse "triunfo", o desejo do autor de Les fleurs du mal em sua apologia à maquiagem e ao artifício? Trata-se, pois, de uma consequência ou da própria continuidade de especulações e reflexões iniciadas entre os precursores do Simbolismo.

Em Portugal, ainda no século XIX, a figura do poeta nas nuvens, do artista encastelado ou longe do mundo comum e corriqueiro, foi muito marcante, e, além de simbolistas, ficaram conhecidos também como "nefelibatas". Constatamos então que o escapismo, o abstracionismo, o idealismo e a mística frequentemente presentes em autores simbolistas portugueses e franceses, fez parte também da poesia de autores como Sá-Carneiro, com seu mundo à parte, de sonho, de ânsias e suas viagens líricas, e José Régio, lírico do sofrimento (à la poetas românticos), e da fuga para o transcendente e o ilusório.

É certo que a poesia presencista (com Régio como seu máximo expoente) jamais chegou ao esteticismo e ao espetáculo da linguagem como a dos poetas do Orpheu e os simbolistas, o citado ensaio de Eduardo Lourenço, "Presença ou a contra-revolução do 
Modernismo português" faz observações certeiras sobre tais fatos[2] (LOURENÇO, 1988, p.144); porém, essa poesia deu continuidade, como também o próprio crítico o atesta, em outro texto, ao ambiente profuso, simbólico, fantasioso e idealista (de culto à interioridade do sujeito lírico) da estética simbolista, e é por isso que Lourenço refere-se à geração presencista como "último avatar" (1983, p.49) da lírica simbolista, em ensaio sobre Cochofel.

\section{O Neo-Realismo e as configurações poéticas simbolistas/decadentistas}

No final da década de 1930, quando então a Presença já era publicada há mais de dez anos, surgiram autores jovens e muito polêmicos, preocupados com a situação que o mundo ao seu redor vivia: os neo-realistas. Vários deles lançavam artigos em jornais e revistas culturais lusitanas, como O Diabo, semanário do Porto, e a revista Sol Nascente, de Lisboa, e talvez seja preciso sublinhar que alguns desses jovens não eram poetas nem artistas, mas pensadores, preocupados com a situação de Guerra e ditaduras daquela época, e engajados no marxismo. Por isso, sua visão da arte era bastante polêmica e restrita: arte social, arte com conteúdo político, arte preocupada com conteúdo, em detrimento da forma. E, surgindo em um contexto em que os poemas presencistas tinham grande força, e versos de José Régio como "Sou, como as nuvens sou que nada são, / e as ondas frágeis como vãs quimeras, / e as pétalas e as folhas desfolhadas, / E as formas fogo-fátuos da ilusão...” (RÉGIO, 1970, p.92), ou "Cabeça ao vento / Febre nos olhos, / Vou suicidar-me de escuridão...” (RÉGIO, 1969, p.15), eram a tônica literária, foi com furor e bastante ingenuidade que iniciaram os ataques a este grande poeta português e também ao que chamavam de "arte desumanizada" (porque leram Ortega y Gasset) e "literatura decadente": enfim, uma poesia considerada "subjetivista" e oposta aos interesses do Homem (concebido, então, única e exclusivamente como ser social).

É bastante evidente que as ofensivas eram dirigidas tanto a Régio como a todo o imaginário simbolista que ainda permanecia em meados do século XX. Os poetas eram 
acusados de ser "subjetivistas" (em alguns momentos usavam o termo "individualista" e "idealista"), aliás, a poesia era acusada de assim o ser, e as acusações vindas dos jovens marxistas também tinham como alvo a "arte pela arte" e o "esteticismo". E o que vemos documentadas na imprensa da época, são trocas de farpas que chegaram a ser até mesmo agressivas, entre literatos como o "crítico" Mando Martins e o poeta José Régio. Apenas para exemplificar o que dizemos, cabe aqui narrar a polêmica iniciada pelo primeiro quando, em 1937, publicou na revista Sol Nascente um artigo que, embora reconhecesse Régio como um dos poetas mais originais de sua época, afirma não ser ele um poeta de qualidade, acusando-o de "delírios", "espetáculos" e "egoísmo" e de fazer uma poesia inútil, cujos versos "não comovem o leitor", dados seus "histerismos malucos" e a "constante obsecação de si" (MARTINS, 1937, p.13). Muito polêmico e pouco interessado em questões de fato estéticas, o artigo de Martins terminava com a seguinte afirmação: “As suas poesias são belas como êsses maravilhosos objetos de luxo das salas de visitas ricas, muito belos, mas inúteis para qualquer coisa" (MARTINS, 1937, p.13, negrito nosso). Vê-se, neste caso, que ao jovem crítico nada interessava o aspecto formal da poesia, pois sua avaliação do autor dos Poemas de Deus e do Diabo mencionava seu estro (e por isso mesmo o tomava como original), mas desmerecia completamente sua obra poética por questões tão somente temáticas e imagísticas[3] - e, enfim, ideológicas, devido à noção de "utilidade" da arte, então defendida.

O fato é que toda nova tendência literária surge tentando desmoralizar a anterior, e, neste caso, como a Presença não possuiu um programa literário com preceitos estilísticos e formais, mas deu continuidade ao que vimos ser uma reafirmação de traços poéticos surgidos no Simbolismo, os neo-realistas fizeram oposições aos presencistas e, por consequência, a vários traços da poesia desde o oitocentismo, como a imagem do poeta nas nuvens ou na torre de marfim, a imagética "vaga" e o hermetismo.

Ademais, tanto estes autores exaltados e engajados quanto os artistas envolvidos com o Neo-Realismo - os romancistas Alves Redol e Manuel da Fonseca e os poetas Carlos de Oliveira, Mário Dionísio e João José Cochofel, por exemplo - tinham uma preocupação: anular definitivamente nas artes os resquícios deste imaginário ou "espírito" da poética simbolista/decadentista na literatura feita por eles. Para os autores 
dos textos polêmicos, a tarefa mais fácil era atacar; para os romancistas, não houve grande problemas, já que o gênero tem especificidades que comporta muito bem o social; mas para aqueles que foram realmente poetas (e não apenas escritores emocionados e motivados por crenças filosóficas e políticas), a tarefa era mais difícil, afinal, é ao Simbolismo que se atribui a grande renovação e revitalização da poesia moderna.

Contudo, cumpre salientar que o problema, para tais artistas, era muito mais temático do que formal. Ora, o que se desejava evitar era exatamente aquilo que Seabra Pereira chama de "espírito e temas" da poesia simbolista, não a poesia em si. Os autores do "Novo Cancioneiro" que se dedicaram ao gênero poético até o fim da vida, como dom artístico e não como missão político-social, Mário Dionísio, Carlos de Oliveira e João José Cochofel, não deixaram para trás todas as descobertas do oitocentismo. Se por um lado uma postura idealista, no gênero lírico, poderia tornar o poema mais hermético e de difícil penetração, o que não se desejava entre os autores de poesia da coleção neorealista, além de ser contrária à filosofia materialista, por outro, não é correto afirmar que a preocupação social ou simplesmente a crença no materialismo, como acontece com João José Cochofel, reduziria a poesia a simples panfleto.

\section{Sol de Agosto: a arte poética como solução de conflitos}

Tal problema, o autor de Sol de Agosto resolveu-o bem. Sua obra poética é reconhecida como a autêntica lírica dentro do Neo-Realismo, e sem ser combativa, eloquente, anunciadora de lutas e acusativa, como muita poesia menor do Novo Cancioneiro. Dentro da polaridade renúncia/denúncia, o poeta encontrou um lugar muito próprio, que não se coloca em nenhuma das duas posições. Há poemas em que a postura é de recusa, e Eduardo Lourenço, embora não desenvolva a ideia, refere-se a Sol de Agosto como obra de um poeta movido "contra o lirismo simbolista de que o presencismo seria o último avatar”. (LOURENÇO, 1983, p.49).

João José Cochofel é, como afirma Fernando Guimarães, um poeta intimista; comparando sua poesia com a presencista, o autor do ensaio "A poesia de João José Cochofel" afirma: "enquanto nestes poetas [da Presença] o subjetivismo se torna 
amplificante, em Cochofel instaura-se, pelo contrário, uma dimensão de interioridade, um intimismo" (GUIMARÃES, 1988, p.12). De fato, desde Sol de Agosto, é desta fala intimista que depreendemos a crença em um mundo concreto, sensível, que só pode ser apreendido pelo contato com o sujeito, e não de manifestações ideais ou da transcendência. Idealismo, transcendência e misticismo, tudo o que for abstrato é refutado por essa poesia que, formalmente, é enxuta, breve, oposta a todo tipo de espraiamento discursivo[4] - porque manifesta a contenção de um sujeito face ao real circundante. Neste sentido, Cochofel é o mais lírico entre os poetas neo-realistas, pois diversos autores referem-se ao gênero pelo seu "fenômeno de interiorização" (MERQUIOR, 1997, p.32), ou, pela necessidade da "individuação" (ADORNO, 2006, p.66) no processo lírico.

No primeiro poema do livro de 1941, o eu-lírico de Cochofel pergunta-se, em estrofes paralelas: "Que posso eu querer do Céu, / se na terra há um sol de Agosto / e a vida canta da alva ao sol posto? // Que posso eu querer de abstracto / [...]" (COCHOFEL, 1988, p.65). Trata-se do questionamento de um "eu", em primeira pessoa, mas o objeto da reflexão no poema é o que este "eu" deve desejar: o material sensível ou o transcendente. "Céu" e "abstracto" encontram-se em versos idênticos, formando um paralelismo que os iguala, e opostos a "sol" (de Agosto) e "vida". Neste caso, a vida é também vivência, e "sol”, palavra frequente nas composições poéticas do autor de Búzio, é aqui, como na maioria delas, aquilo que desperta o sujeito para as coisas que o cercam: sol quente, sol iluminado, calor na pele e luz para os olhos.

Palavra frequente no que chamamos "retórica neo-realista" (presente nas obras do Novo Cancioneiro), em geral, "sol” representa razão, clarão oposto à escuridão política da época (de ditadura salazarista); porém, em Cochofel, sua configuração é mais profunda e singular, pois é o sol um elemento que chama o eu-lírico dos poemas para a vida, para o que está a sua volta, afastando-o da tentação (sempre existente na obra do autor) de entregar-se à divagação, à sua interioridade ou ao "abstrato". "Sol", em Cochofel, é quase que uma salvação para o perigo de tornar-se um "individualista".

Assim ele se apresenta no poema "VII": 
Sol que acordou em mim

o grão do meu instinto!

Ergo-me

só pelo que sinto.

Basta-me o hálito a terra

da tua nudez reflorida.

Sonhos? - Quem se evade da vida, se é vivida?

(COCHOFEL, 1988, p.71).

Notemos que é ele, o "sol" que "acorda" algo no sujeito lírico. Como em boa parte de seus poemas, o autor utiliza em duas estrofes seguidas (os dísticos) vocábulos para expressar a mesma coisa, isto é, "acordar" e "erguer-se" são metáforas para o mesmo movimento no eu poético, e este é movido por "instinto" / "sinto". Com efeito, estas palavras não apenas rimam entre si, mas também se igualam: representam a relação do sujeito com o mundo, calcada no "instinto" e no verbo "sentir" que, ao contrário do que se pode pensar, não tem relação com sentimento, vida interior, mas com os sentidos. Sentir o quente e o frio, sentir odores, sentir o mundo a sua volta, sentir o corpo na relação amorosa, e usar os instintos. Aliás, a última possibilidade levantada, da relação amorosa, não só está no poema como em várias outras composições do autor que, além de dar sensualidade à mulher -, também vive com ela momentos de erotismo desvendados sutilmente nas composições.

Assim, no poema sétimo, não apenas a relação do homem com o mundo se mostra: em outra camada de leitura, está o encontro com o "tu", encontro carnal. "Sol", "acordar" e "erguer-se" também podem ser lidos como o desejo, que, por sua vez, não permanece na "ideia" do sujeito, na idealização do amor, mas no concreto: o "hálito", a "terra", "da tua nudez reflorida". A mulher verdadeira, nua, as coisas como são apresentadas aos sentidos: eis a matéria cantada por Cochofel, neste poema finalizado com a recusa total da fantasia: "Sonhos? - quem se evade da vida, / se é vivida?".

Os recursos sonoros utilizados pelo autor nesse poema são a recorrência do som nasal nas duas primeiras estrofes - "mim", “instinto", "sinto" - e a rima. O poeta poucas vezes metrifica suas criações, tornando-as fluidas como uma fala ritmada e 
breve, mas bastante musical. Eduardo Lourenço alude à "modéstia poética" nas composições poéticas do artista, presente no fato de ele "não erguer a voz além do que basta para que a ouçamos" (LOURENÇO, 1983, p.32); e os procedimentos de que mais se utiliza, o verso curto, as poucas assonâncias e aliterações, as rimas em parte dos versos e o paralelismo, são parte desse tom baixo e colaboram para o sentido de vivência sensível que sua poesia aponta, a clareza manifesta na relação do sujeito com o mundo é também parte de suas opções formais.

Mas um diálogo maior com o imaginário e a temática simbolistas está no quinto poema de Sol de Agosto:

Rebenta em mim um mar de força. É maré cheia! Mar que atiro à praia, seguro e rijo, Sem que o tolham loas de sereia.

E a vida já me doeu...

Mas não tomei ópio nem olhei o céu, embora chorasse como os vencidos.

Agora é sol e sangue

o búzio que trago nos sentidos.

(COCHOFEL, 1988, p.69).

São evidentes as oposições à evasão e a qualquer forma de transcendência no poema: seja pela recusa às "loas de sereia" - o canto mágico e hipnótico que tira o sujeito do mundo real -, às drogas ou ao apelo místico (configurado na atitude de "olhar" o "céu").

O poema expõe, na primeira estrofe, a luta do eu-lírico contra a "maré cheia" de sentimentos e inconstâncias interiores, a metáfora criada no primeiro verso, "rebenta em mim um mar de força” transforma em imagem o acontecimento que se dá na sua interioridade, e a dificuldade de se livrar de tal acontecimento - sentimentos, talvez? Angústia, medo, dor? -, esta "luta", pode ser depreendida da semântica de verbos como "rebentar" e "atirar" e na postura "rija" deste eu poemático. 
É interessante notar que no verso "Sem que o tolham loas de sereia", há uma assonância em "o" e "a", um som que parece imitar o encantamento do canto das mulheres da água, e, ao mesmo tempo, pode nos remeter no canto de outra poética, na musicalidade excessiva de versos orquestrados de poetas de outrora.

O poema evolui, então, da postura de recusa à de afirmação: na segunda estrofe, os verbos conjugados no passado indicam uma atitude anterior ao movimento de "atirar" o "mar de força"; depois, na última estrofe, é o "agora" que se canta, e este é feito de "sol" e "sangue", elementos vitais, que "são" o "búzio" do sujeito poético. Neste ponto da composição, é possível analisá-la como afirmação de uma nova poética de seu autor; Búzio é o título de seu livro anterior, publicado dois anos antes (em 1939), em que ainda são visíveis temas e traços poéticos da Presença e das correntes líricas do final do século XIX e início do XX[5]. Portanto, este "agora" o "búzio", o canto, a obra poética do autor é "sol" e é também "sangue" - notemos que o verbo "ser" iguala os três vocábulos, e temos assim uma poesia que nasce daquilo que é vital, e alcança os sentidos: "sol" remete-nos à luz e à temperatura do corpo; "sangue" possui cor realçada, e, em geral, brota da dor, do ferimento, do contato com a pele. E é, enfim, nos "sentidos", na experiência sensível, que o sujeito lírico desta composição carrega seu "búzio" - e o poeta pode, assim, estar reafirmando sua poética da vivência, do sensualismo, do real circundante, da experiência concreta, ou, nas palavras de Lourenço, da "Imanência" (1983).

Certamente, esta atitude manifestada nos poemas do terceiro livro de Cochofel, deriva de suas opções filosóficas, mas o autor não propaga filosofias, tampouco evidencia um cantar engajado. Da mesma forma, mais do que a simples oposição à poesia idealista ou cunhada por neo-realistas como "subjetivista", as recusas presentes nos poemas de Sol de Agosto é refutação de filosofias idealistas, mas, em consequência disto, o autor acaba opondo-se ao canto com tendências místicas, à evasão e ao artifício. Pois é o "real" que o inspira: "O concreto, o real, coisas que me comovem. / É sobre os sentidos que vivo debruçado. / Fácil o que a vista enxerga. / o resto é-me vedado." (COCHOFEL, 1988, p.75). 
Em parte, também estamos diante da questão da inspiração, ou seja, daquilo que toca o poeta a ponto de ele criar, e também de seu modo de criar, afirmado em seus poemas em contraste com outras poéticas, como no poema "III": "Não me venham dizer / que os choupos despidos lembram mágoas, / se o sol os veste, solitários e altivos, / erguidos sobre as águas.”(p.67), em que a imagem do "choupo", cantado por poetas simbolistas como Paul Verlaine, na França, e António Nobre, em Portugal, é refutada enquanto ponto de transfiguração para os sentimentos líricos do eu poético.

Essa recusa do imaginário poético anteriormente descrito em poucos momentos vale-se dos procedimentos mais conhecidos entre poetas engajados; enquanto seus colegas de grupo usavam excessivamente a voz coletiva, com o verbo na primeira pessoa do plural, afirmando assim a derrocada do "eu", Cochofel escreveu vários poemas em primeira pessoa, e quando os versos são compostos por verbos no plural, o sujeito está sempre indeterminado, como se fosse um "vós" ou um "eles", cabendo ao leitor imaginar quem são. É assim na continuação do décimo primeiro poema (“O concreto, o real..."), em que a segunda estrofe apresenta os versos: "Cerquem-mede tojos. / Embora! [...]" (p.80)[6] - sugerindo uma resistência a não se sabe bem quem ou o quê; e também no poema "II", cuja última estrofe metaforiza a postura de se olhar o que está na "flor do mundo", na superfície: “Assim deito meus olhos à flor do mundo. / Nem me peçam mais: / os lagos serenos têm menos fundo" (p.66).

Do mesmo modo, a grande frequencia com que a poesia neo-realista usa o verbo no modo imperativo, ordenando aos homens a opção pelo combate ou pela resistência, configurando um discurso engagé, não está na poesia do terceiro livro de Cochofel, no qual o imperativo aparece somente em dois poemas de Sol de Agosto. Em um deles, o diálogo com a poética simbolista/decadentista e seus resquícios no século XX pode ser pensado na recusa ao "desânimo" ou às "complicações de alma":

\section{XVII}

Sem frases de desânimo nem complicações de alma, que o teu corpo agora fale, presente e seguro do que vale. 
Pedra em que a vida se alicerça, argamassa e nervo, pega-lhe como um senhor e nunca como um servo.

(COCHOFEL, 1988, p.81).

Trata-se de um poema bastante didático, claro, de recorte clássico: a metáfora da "pedra" é simplificada por referir-se a "corpo", e torna-se ainda mais explícita quando a idéia de construção é configurada também com a mistura de "argamassa" e "nervo". Assim, não há ambiguidade, tão cara à metáfora poética, nesses versos de Cochofel; o que os torna mais líricos é a composição métrica - variada entre cinco e oito sílabas poéticas, mas com acentuação difusa, o que aproxima os versos e agrada o ouvido -, as rimas e algumas aliterações e assonâncias em paralelismo - "Sem / nem"; "Pedra / pega" - formando recorrência sonora e corroborando o ritmo do poema.

Parece-nos pertinente ler o texto como a recusa de qualquer misticismo ou forma de religiosidade, em favor da matéria (corpo). Embora Eduardo Lourenço afirme que a poesia de Cochofel nem sequer toque no tema "religião", tornando-se "inocentemente atéia" (LOURENÇO, 1983, p.46) - e o autor usa o advérbio para afirmar que na obra do poeta a questão religiosa é nula, diferente das de seus colegas neo-realistas, que "atacam" sobretudo a religião cristã - este poema sugere-nos uma tripla refutação: em relação ao idealismo, em relação às poéticas "subjetivistas" e em relação à religião. A figura da "Pedra" como o alicerce da vida pode ser confrontada à "pedra" em que a igreja cristã fundou-se, no apostolado de Pedro. E a própria atitude de ser "senhor" do seu corpo é também uma forma de recusar o senhorio de Deus.

Quanto à refutação ao idealismo, salientamos que "XVII" é um dos raros poemas de Sol de Agostoem que se torna evidente não só a opção neo-realista como a crença marxista do autor. Os termos "senhor" e "servo" podem também nos remeter à dialética de Marx[7], fundada nas relações sociais ao longo da história, em que o "servo" feudal, contraponto do dominador "senhor", é superado pela burguesia, mas esta tem como seu contraponto o proletariado: é a eterna luta, na filosofia marxista, entre opressores e oprimidos que é então retomada. Do mesmo modo, a questão do valor do corpo configura uma referência ao trabalho e à alienação. Aliás, as duas 
leituras, de refutação religiosa e afirmação materialista estão intrinsecamente relacionadas, já que o marxismo é uma filosofia completamente hostil à religião. Enfim, o sujeito poético nega também toda criação em que tais preceitos recusados se encontram, e é certo que, considerando a economia de Sol de Agosto, mais uma vez o poeta opõe-se a qualquer repertório místico e até mesmo disfórico inerentes a poéticas advindas do fin-de-siècle.

Há um equilíbrio em Sol de Agosto: se a maioria das criações poéticas nele inseridas expõem as recusas mencionadas e a afirmação dessa nova poesia do autor, são poucos os poemas mais engajados e a eles se opõem aqueles, também minorias, em que o poeta abandona a necessidade de recusa/afirmação, para então tratar de temas mais universais, como o amor e a memória. Pois como lírico que sempre foi, o autor de $O s$ dias íntimos não deixou escapar tais inspirações, surgindo sempre intercaladas com os poemas de recusa do abstrato e afirmação do concreto, como se o poeta não quisesse se "dispersar" entre os motivos e temas que poderiam fazê-lo trair o propósito de não sair do mundo sensível. Portanto, a terceira obra do autor não representa somente um diálogo com poéticas recusadas e a afirmação da sua própria, mas também momentos de memória: "Saudade de uma coisa / que a memória, só ela, / realiza ainda / Lembra e dói / apenas porque é finda" (COCHOFEL, 1988, p.72), - e notemos que tais versos são quase que opostos à afirmação certeira de não serem permitidas "frases de desânimos" ; e de amor: "Dá-me as tuas mãos: / entre nós, nem ciúmes, / nem medo // O dia, hoje, / teceu grinaldas para os nossos dedos" (p.70).

Enfim, a crítica Rosa Maria Martelo, em estudo dedicado à obra de Carlos de Oliveira, menciona rapidamente seu colega João José Cochofel, afirmando que:

o idealismo, a transcendência, o abstracto, o invisível são valores filosóficos epoéticos que comparecem, em Sol de Agosto, como as exclusões relativamente às quais se produz o sentido da opção materialista [de Cochofel] (MARTELO, 1998, p.114, negrito nosso).

Com efeito, na última composição da obra, o poeta faz uma espécie de resumo de sua transformação neste livro e do que vivenciou na atividade poética então exposta: “Já me não dá amargos de boca / o mundo. / Sei o que quero desta vida oca: / não me 
confundo" (COCHOFEL, 1988, p.82). Apoiado, sobretudo, na rima, esse poema é a síntese das escolhas do sujeito lírico das criações anteriores, e é nele que se constata que, confuso, magoado, sentimental, preso ao passado - apegado ao mundo interior, subjetivo - o poeta só pode estar mudo:

Excesso de lembrança, dor que outra dor levanta. Xadrez de quem vive sozinho e não canta.

E essa "exclusão" (para usar palavra de Martelo) de tais categorias enquanto poéticas leva, como vimos, o sujeito lírico a um diálogo de recusa do imaginário advindo de Simbolismo/Decadentismo, com suas imprecisões, sua transcendência, sua busca do "ideal" (tão cantado em Baudelaire), sua individualidade extremada. A arte poética de Cochofel, na inseparável paridade forma/conteúdo, reflete tal "opção", na simplicidade e clareza do canto, nos procedimentos recorrentes em sua poesia (rimas, paralelismo e metáfora), e, sobretudo, na brevidade do poema, na concisão que é, em última análise, a contenção de um eu-lírico que não se deixa levar pelos apelos do subjetivo, do ideal e do abstrato, o que é difícil na arte lírica.

Com seu quarto livro, o autor coimbrão travou, com êxito, uma luta contra tais dificuldades, uma a mais, neste universo que é o das palavras poéticas. E os poemas de Sol de Agosto e os dos próximos livros do autor (cuja obra resume-se somente à poesia e a ensaios, jamais à narrativa, prova de sua veia poética) são suficientes para a apreciação de seu êxito artístico diante da escolha de uma poesia do concreto, ou da "imanência", e da filiação a uma tendência literária tão estranha à poesia, como foi o Neo-Realismo.

\section{REFERÊNCIAS}

ADORNO, T. Lírica e Sociedade. In: Notas de Literatura I. Trad.: Jorge de Almeida. São Paulo: Duas Cidades/ Editora 34, 2006.

BAUDELAIRE, C. Oeuvres Complètes. Paris: Gallimard, 1968. 
CHIAMPI, I. (coord.). Fundadores da Modernidade. São Paulo: Ática, 1991.

COCHOFEL, J. J. Obra poética. Lisboa: Caminho, 1988.

CRUZ, G. A poesia portuguesa hoje. Lisboa: Plátano, 1973.

FRIEDRICH, H. Estrutura da lírica moderna: da metade do século XIX a meados do século XX. Trad.: Marise M. Curioni e Dora F. da Silva. São Paulo: Duas Cidades, 1978.

GUIMARÃES, F. O modernismo português e a sua poética. Lisboa: Lello, 1999. Moeda, 1990.

A poética do Simbolismo em Portugal. Lisboa: Imprensa Nacional- Casa da

. Simbolismo, Modernismo e Vanguardas. Porto: Lello \& Irmão, 1992.

. A poesia de João José Cochofel. In: COCHOFEL, J. J. Obra poética. Lisboa: Caminho, 1988. p.9-16.

LOURENÇO, E. Sentido e forma na poesia neo-realista. Lisboa: Ulisséia, 1983.

. 'Presença' ou a contra-revolução do Modernismo português?

In:__ Tempo e Poesia. Lisboa: Relógio d'água, 1987.

MARTINS, M. 'José Régio - Casais Monteiro. Poetas'. In: Sol Nascente. Quinzenário de Ciências, Arte e Cultura. Porto: 01 de dezembro de 1937. no.20, p.13.

MARTELO, R. M. Carlos de Oliveira e a referência em poesia. Porto: Campo das Letras, 1998.

MERQUIOR, J. G. Natureza da lírica. In: A astúcia da mimese: ensaios sobre lírica. 2.ed. Rio de Janeiro: Topbooks, 1997.

MARTINO, P. Parnasse et Symbolisme. Paris: Librairie Armand Colin, 1958.

MICHAUD, G. Message poétique du Symbolisme. Paris: Nizet, 1966.

NOBRE, A. Só. Porto: Tavares Martins, 1955.

ORTEGA Y GASSET, J. La deshumanización del arte (y otros ensayos estéticos). Madrid: Revista de Occidente, 1964.

PESSANHA, C. Clepsydra. Edição crítica de Paulo Franchetti. Campinas: UNICAMP, 1994.

REALE, G., \& ANTISERI, D. História da filosofia. Do Romantismo até nossos dias. São Paulo: Paulus, 1991 (v. III).

RÉGIO, J. Poemas de Deus e do Diabo. Lisboa: Portugália, 1969. Mas Deus é grande. Lisboa: Portugália, 1970.

SÁ-CARNEIRO, M. Poesia. Org. Fernando Paixão. São Paulo: Iluminuras, 2001. SIMÕES, J. G. António Nobre. Precursor da poesia moderna. Lisboa: Inquérito, [19_]. 
[1] O estudo Parnasse et Symbolisme (1958), de Pierre Martino, mostra que a poética parnasiana do rigor formal tem continuidade no Simbolismo francês, e que Gautier (a quem Charles Baudelaire dedicou Les fleurs du mal) e sua convicção na "arte pela arte" estiveram presentes nas manifestações poéticas do Simbolismo.

[2] As transformações poéticas desde o Simbolismo, aqui já referidas, são analisadas pelo crítico português (sem operar as relações com a poética oitocentista como aqui fazemos) no âmbito deOrpheu. Para ele, características da lírica órphica como a espetacularização do leitor, a criação de um mundo poemático calcado unicamente na linguagem, e sua decorrência, a despersonalização, são levadas ao extremo com destro por autores do primeiro modernismo português, enquanto no caso de poetas presencistas como Régio ou o primeiro Torga, dá-se o contrário: a personalidade lírica é um "dado" no poema, esse sujeito lírico é o espetáculo, havendo, assim, a espetacularização do eu poemático. Trata-se, sob estes aspectos, de uma postura mais romântica do que simbolista.

[3] O artigo deu início a uma série de outras publicações em forma e réplicas e tréplicas da parte de Régio e de Martins, e é certo que tais polêmicas, tão vivas na época, ajudaram a formar o conceito mais comum que se tem não sobre a jovem crítica neorealista, mas sobre as criações literárias do grupo, sobretudo no tocante à poesia, pouco lida, mas discutida à luz das ideiasengagées dos autores de ensaios e artigos mais polêmicos.

[4] Expressão certeira, que tomamos emprestada de Guimarães (1988, p.10).

[5] Os dois primeiros livros do autor, Instantes e Búzio são bastante devedores desse imaginário que a partir de Sol de Agosto ele passa a refutar. No trabalho de doutorado que desenvolvemos e em outros textos, tivemos a oportunidade de comentar mais profundamente essa influência presencista e também simbolista na primeira poesia de Cochofel, em que imagens vagas, indecisas e evasão estão presentes em grande parte dos poemas (sobretudo na primeira obra). Para que o leitor tenha uma idéia, versos como "A minha alma é como o sol, / declinando, / que vai dourando tudo" (COCHOFEL, 1988, p.31); "Um vago bem estar / feito de alegria e de tristeza... [...] Porque não? / - ficar assim eternamente / a vê-las dançar / e a sonhar coisas vagas." (p.261); "A minha poesia / é toda feita de melancolia; eu de fatalismo. / No íntimo, / há coisas vagamente pensadas, / vagamente...” (p.270) são frequentes em seus primeiros livros e contrastam claramente com as composições de Sol de Agosto, no tocante à metafórica e às imagens criadas. Do mesmo modo, tais poemas eram longos, em contraposição à brevidade, marca de sua poesia a partir da coletânea de 1941.

[6] Na edição da poesia completa do autor, utilizada neste trabalho, o poema "XI" aparece dividido em dois: "O concreto, o real, coisas que me comovem / é sobre os sentidos que vivo debruçado. / Fácil o que a vista enxerga / o resto é-me vedado" como décimo primeiro; e "Cerquem-me de tojos. / Embora! / Esperarei suas flores amarelas / Em Agosto / maior será minha ânsia de vê-la", como décimo sexto. Porém, na própria edição há a nota explicativa de que, na versão primeira do livro, os dois eram só um, e configuravam a décima primeira composição da obra. Como utilizamos a edição de 
1988, referimo-nos às páginas separadamente, ainda que no artigo analisemos "os poemas" como um só.

[7] Para saber melhor sobre a dialética marxista e seu materialismo histórico, pode-se consultar Giovani Reale e Dario Antiseri, 1991, p.196-199. 